\title{
The lack of relationship between reported self-care, and the factors that influence blood hypertension, in Costa Rican patients
}

\author{
Lourdes Arce Espinoza ${ }^{1}$, Julián Monge Nájera² and María Isabel González Lutz ${ }^{3}$ \\ ${ }^{1}$ Servicio Médico, Universidad Estatal a Distancia, 474-2050 San Pedro, Montes de Oca, San José, Costa Rica; larce@uned.ac.cr \\ ${ }^{2}$ Vicerrectoría de Investigación, Universidad Estatal a Distancia, 474-2050 San Pedro, Montes de Oca, San José, Costa Rica; julianmonge@gmail.com \\ ${ }^{3}$ Escuela de Estadística, Universidad de Costa Rica, 2060 San José, Costa Rica; mariaisabel.gonzalezlutz@ucr.ac.cr
}

Received 31-V-2010 Corrected 28-VII-2010 Accepted 16-VIII-2010

\begin{abstract}
Hypertension is a major health problem worldwide, and its control depends on a good level of self-care, a subject that in Latin America has not been studied in university personnel. We wanted to know if factors known to affect the development of hypertension, also had a relationship with self-care in patients, and for this, we interviewed 80 hypertense university employees who visited the medical service of an university in Costa Rica from January 14, 2002 through December 15,2008 . They answered a questionnaire that we wrote based on the Morinsky and the Martin-Bayarre-Grau questionnaire. Age, sex, education, medical history, treatment and relationship with health personnel showed no association with the level of self-care reported by patients. In a 1-100 scale, the majority of patients scored between 75 and 90 points, indicating that they reported high levels of self-care. Our direct personal experience with these patients indicates that reported self-care is consistent with their hypertension control levels. This kind of study is not new in developed countries, but fills an important gap in our knowledge of health in Latin American university personnel.
\end{abstract}

\section{KEY WORDS}

Self-care, risk factors, hypertension.

\section{RESUMEN}

La hipertensión arterial es un problema de salud importante actualmente a nivel mundial, cuyo control depende de un buen nivel de autocuidado, tema que no ha sido estudiado en personal universitario de América Latina. Queríamos saber si los factores que se sabe favorecen la hipertensión arterial, tenían relación con el nivel de autocuidado en los pacientes. Entrevistamos para ello a 80 empleados universitarios hipertensos que consultaron el servicio médico de una universidad costarricense entre el 14 de enero de 2002 y el 15 de diciembre de 2008 . Se les aplicó un Cuestionario de Evaluación de Adherencia Terapéutica en Pacientes Hipertensos, de elaboración propia a partir de la prueba de Morinsky y del cuestionario Martin-Bayarre-Grau. La edad, sexo, educación, historial médico, tratamiento y relación con el personal de salud no tuvieron asociación con el nivel de autocuidado informado por los pacientes. Dentro de una escala de 1 a 100, la mayoría de los pacientes obtuvo entre 75 y 90 puntos, lo que indica que reportan altos niveles de autocuidado. Nuestra experiencia con estos pacientes indica que el autocuidado que informan tener es coherente con los niveles de control de su hipertensión. Este tipo de estudio no es nuevo en países industrializados, pero llena un vacío importante en nuestro conocimiento de la salud en personal universitario latinoamericano.

\section{PALABRAS CLAVE}

Autocuidado, factores de riesgo, hipertensión arterial.
High blood pressure -or briefly, hypertension- is among the chronic diseases that produce the highest rates of morbidity and mortality in the world. It often is the main cause of consultation in medical service. Furthermore, its close relationship with heart disease has established hypertension as a life expectancy predictor, along with family history and age (Suárez et al. 2000).
Many of the developing countries in Latin America are changing their mortality and morbidity patterns. In the past, transmissible diseases were the main sanitary problem; but today, non-transmissible diseases are becoming more important (OPS 2007). This change reflects modifications of the traditional way of life (including eating habits) brought about by globalization. Despite the importance 
of this change, the information available on the subject is relatively scarce (OPS 2007).

In Central America, the main factors associated with hypertension include weight, sex and lifestyle. In addition, it has been documented that the risk of hypertension is directly associated with increasing age (Cerrato \& Zambrano 2009, OPS 2007).

In Costa Rica, 59\% of the older population suffers from hypertension, and the female population is the most affected. Within this group, the main risk factors are: age over 70-years, high body mass index and family history. Other less determinant factors include having more than six years of formal education and consuming more than 3000 calories per day (Méndez-Chacón \& Rosero-Bixby 2007).

Patients' self-care is very important in controlling hypertension, specially, adherence to therapy, which is the degree to which the person follows the medical recommendations about taking medication, following a food regime and changing lifestyle (World Health Organization 2004).

Improper self-care has been considered one of the biggest problems in patients with chronic diseases. For example, when medication is abandoned prematurely, it is not possible to evaluate the efficiency of treatment, the risk of developing other pathologies increases and the economic cost of care grows, because more resources must be used for the attention of chronic unbalanced diseases (Ortiz et al. 2007). Low adherence is a complex and pervasive problem that in extreme cases can reach $90 \%$ of cases (Márquez-Contreras \& Figuera-Von Wichmann 2009).

Hypertension is a multifactorial disease and often depends on multiple pharmacological combinations for control. However, health agencies have found that if the patient's self-care is low, no pharmacological treatment will be successful. Poor self-care causes a persistence of hypertension that can be erroneously interpreted as organism resistance to a particular treatment (Johnell et al. 2005), leading to an unnecessary change in the therapy.

Many of the factors involved in adherence and other aspects of self-care are not innate, so they must be learned or acquired during the early stages of treatment. Reaching a good level of self-care may result from an active commitment of the patient to controlling the disease (Ehremzweig 2007). This commitment is reinforced by an environment that facilitates an active lifestyle and a good diet, as well as by the support of social networks composed of family, friends and people from their working place (Holguín et al. 2006).

A previous study about the staff of a Costa Rican university found that women and men with hypertension do not differ significantly in personal characteristics, the environment where they live and work, or the relationship with doctors (Arce \& Monge-Nájera 2009), but the factors that influence their level of self-care were not studied. In this article, we searched for associations among self-care, sex, occupation, academic level, disease history, opinion on hypertension and its treatment, degree of communication with their physicians and stress indicators in their homes. We selected these variables because they are known to affect the development of hypertension, and we wanted to see if they also had a relationship with self-care in patients (Arce \& Monge-Nájera 2009).

\section{METHODOLOGY}

\section{Data collection}

We worked with the staff of one of the main Costa Rican universities. One of us (L.A.) read the medical records of everyone in the institution's staff ( 1526 records from January 14, 2002 through December 15, 2008) and listed the 179 patients with hypertension. Blood pressure is measured in all patients that visit the clinic, even if they are not known to have blood pressure problems, and the measurement is done every time the patient is seen by a physician (the WHO standard procedure is followed).

The records indicated that only 179 of the patients suffered from hypertension, but some were no longer patients of the clinic and we were unable to interview them. Others did not accept, so the final sample consisted of 80 hypertense patients who agreed to participate in the study.

To keep the application homogeneous, the first author personally interviewed everyone of the 80 patients in the privacy and quiet of a clinical room. Each patient was interviewed individually with a Questionnaire for the Evaluation of Therapeutic Adherence in Hypertense Patients (Appendix 1) that we wrote based on the Morinsky test and on the Martin-Bayarre-Grau or "MBG" questionnaire (García et al. 2000, Martin et al. 2008). We wrote our own instrument because none of the above questionnaires covered by itself all the variables that we wanted to measure.

\section{Statistical analysis}

We constructed a self-care index composed of the sum of scores in the questionnaire (for each question: 1=low, $2=$ intermediate, $3=$ high self-care; maximal possible total score $=100$ indicating patients that behaved in all aspects fully as recommended to control hypertension). To identify which of the factors listed in Appendix 1 were associa- 
ted with the level of self-care, we used a logistic regression (STATA SE version 8 and JMP version 4).

\section{Ethics}

We followed all pertinent ethical guidelines described by Emanuel et al. (2000). Our study provides original and rigorously collected scientific information on a previously unknown subject (there are no previous studies on this population); the results can be used to improve health care in the studied institution and similar environments; we only interviewed patients who were properly informed about the study and accepted to participate and no individual identities are presented or can be identified from this sample that represents $5 \%$ of the total population (i.e. employees of that university). Furthermore, the project was approved by the University Research Division, which includes ethics among its criteria for approval; and no medical treatment was applied to any patients whatsoever because this is an statistical study of replies to questionnaires.

\section{RESULTS}

The age range of the group (39 women, 41 men) was 22-66 years (mean 51 years) and all are residents of Costa Rica's Greater Metropolitan Area. Socioeconomic status and academic preparation were variable, from basic education ( 9 years) to full university education. Marital status: 44 patients were married, 20 single, 11 divorced and four in "free union".

If any patients behaved in all aspects (information, diet, exercise, medication and others) fully as recommended to control hypertension, they would obtain a total score of 100 points in the questionnaire. None did, but the selfcare values were nevertheless high, with most patients scoring between 75 and 90 points (Fig. 1).



FIG. 1. Distribution of patients according to their self-care score. Scores under 45 points are not shown because all patients scored above that value.

$\mathrm{N}=80$ patients, Mean $=79$ points, Standard Deviation $=9$ points. 
The variables that we hypothesized to have a relationship with self-care were age, sex, marital status, education, home environment and level of communication with the physician about the dangers of hypertension and the efficacy and importance of medication and lifestyle. However, the regression analysis showed that none of them had a significant relationship with self-care. Parameter estimates and standard deviations for the main variables appear in Table 1. The complete list of variables can be readily extracted from Appendix 1.

\section{DISCUSSION}

Previous studies have shown that the lack of proper self-care is at the root of low levels in the control of blood hypertension. Those levels can be as low as 10-40 \% (Márquez-Contreras \& Figuera-Von Wichmann 2009). We used a different approach, by quantifying self-care instead of counting how many patients had their hypertension

TABLE 1

Results of analysis of association between self-care and several variables

\begin{tabular}{|c|c|c|}
\hline Variable & Estimation & Standard deviation \\
\hline Intercept & 76,329641 & 4,841292 \\
\hline Adult age group & $-1,485796$ & 3,490205 \\
\hline Older age group & $-0,834508$ & 3,718503 \\
\hline Sex & 0,1831229 & 1,194796 \\
\hline $\begin{array}{l}\text { Marital status: } \\
\text { Single }\end{array}$ & 1,1306138 & 3,005746 \\
\hline $\begin{array}{l}\text { Marital status: } \\
\text { Married }\end{array}$ & 3,0743824 & 2,687081 \\
\hline $\begin{array}{l}\text { Marital status: } \\
\text { Divorced }\end{array}$ & 2,8706567 & 3,366242 \\
\hline $\begin{array}{l}\text { Marital status: } \\
\text { Widower }\end{array}$ & $-5,70623$ & 7,912637 \\
\hline $\begin{array}{l}\text { Complete secondary } \\
\text { education }\end{array}$ & $-0,441001$ & 3,634777 \\
\hline University: Full & 4,0508935 & 5,500075 \\
\hline $\begin{array}{l}\text { University: } \\
\text { Incomplete }\end{array}$ & $-2,270357$ & 2,334664 \\
\hline $\begin{array}{l}\text { Doctor properly } \\
\text { explains importance } \\
\text { of treatment }\end{array}$ & 2,9650932 & 2,131736 \\
\hline $\begin{array}{l}\text { Doctor properly } \\
\text { explains how to } \\
\text { follow treatment }\end{array}$ & 1,8332381 & 1,53369 \\
\hline
\end{tabular}

under control. Our finding was that self-care levels are generally high in this population of university employees. Possibly, this indicates that our patients are committed to controlling the disease and find the medical recommendations reasonably easy to follow. Other studies have found that self-care does not depend exclusively on the environment or social connections, but rather on the patients' commitment to the treatment as well as on its simplicity: patients report more compliance in single dose treatments than in treatments that require several dosages per day (Crespo et al. 2000, Bautista et al. 2003).

Our study shares a weakness with most other studies: frequently, the real levels of self-care are lower than the levels reported by patients (Márquez-Contreras \& FigueraVon Wichmann 2009). This is not the result of conscious lying, but a part of human nature when trying to remember duty fulfillment. Similarly, patients state that low fulfillment of treatment simply is the result of unconscious oversight (Crespo et al. 2000, Bautista et al. 2003). However, the experience of the first author after several years of personally measuring the blood pressure of the studied patients, indicates that in this case their report is reliable because, generally, they have their hypertension under control. An apparent weakness is the lack of a control group, but this is not the case because a control group would have to consist of patients who do not suffer hypertension, and it does not make sense to study self-care for hypertension in patients who do not have it. Thus, our approach is based on a powerful multivariate analysis of patients who have varying degrees of self-care.

The second finding of this study is the lack of association between self-care score and all the measured personal (sex, occupation, academic level, disease history, opinion on hypertension and its treatment, degree of communication with doctors) and environmental variables (stress indicators in their homes) known to influence the development of hypertension (Arce \& Monge-Nájera 2009).

We hoped to find an association because that would be the start of a search for a cause-effect relationship. If we knew which variables caused good levels of self-care, we could manage them to improve the life of these patients. However, our statistical technique did not find any associations. Other studies on self-care (Bardorf et al. 2006, Freedom et al. 2007) have focused on different variables, mainly family support and some not very clear "internal resources" that are considered important for long-term control of hypertension (Rivas et al. 2008). Future studies of this population should be based on the same variables that have been found to be important by other authors (Crespo et al. 2000, Palacín et al. 2002, Holguín et al. 2008). We also recommend a study of the psychological factors 
that result in a high level of self-care (Choo et al. 2001, La Rosa et al. 2007) but insist on the finding that in the population that we studied, self-care is satisfactory at the moment of the study.

\section{ACKNOWLEDGMENTS}

We thank Gioconda Muñoz Hernández for providing the MBG questionnaire; Andrea Sánchez Guevara, for help in data processing, and the participating patients. Special thanks to three anonymous reviewers who helped us to greatly improve a previous draft. This research was funded by Vicerrectoría de Investigación UNED.

\section{REFERENCES}

Aguayo, F. 2007. El estrés psicosocial como factor predisponente de enfermedad aguda en pacientes de medicina familiar del Policlínico Central de la Caja Nacional de Salud, los meses de junio, agosto y septiembre. Revista Paceña de Medicina Familiar 4: 101-105.

Arce, L. \& J. Monge-Nájera. 2009. Género y niveles de adherencia al tratamiento antihipertensivo en el personal de la Universidad Estatal a Distancia de Costa Rica. Cuadernos de Investigación UNED 1: 163-170.

Bardorf, T., F. Hecht, C. Rubow \& J. Gerstoft. 2006. Physicians' communication with patients about adherence to HIV medication in San Francisco and Copenhagen: a qualitative study using Grounded Theory. BioMed Central, Services Research 6: 1-12.

Bautista, A. \& G. Pérez. 2003. Evaluación y manejo actual de la hipertensión arterial esencial. Acta Neurológica de Colombia 19: 69-72.

Benet, C., L. Espinosa, J. Apollinaire \& M. León. 2006. Hiperreactividad cardiovascular en la predicción de la hipertensión arterial en la comunidad. Revista Electrónica de las Ciencias Médicas en Cienfuegos 4: 33-41.

Chacón, D., R. González, G. Velásquez \& O. Segura. 2008. Risk factor analysis associated to hypertension. Correo Científico Médico de Cuba 12: 1-5.

Choo, P., C. Rand, T. Inui, M. Ting Lee, C. Canning \& R. Platt. 2001. A cohort study of possible risk factors for over-reporting of antihypertensive adherence. BioMed Central Cardiovasculars Disorders 1: 1-6.

Crespo, N., J. Rubio, M.I. Casado, J. Sánchez-Martos \& C. Campo. 2000. Factores moduladores de la adherencia farmacológica en hipertensión arterial: estudio exploratorio. Revista Hipertensión 17: 4-8.

Ehremzweig, Y. 2007. Modelos de cognición social y adherencia terapéutica en pacientes con cáncer. Avances en Psicología Latinoamericana 25: 7-21.
Emanuel, E.J., D. Wendler \& C. Grady. 2000. What makes clinical research ethical? JAMA 283: 2701-2711.

Espinoza- Gómez, F., G. Ceja-Espíritu, B. Trujillo-Hernández, T. Uribe- Araiza \& P. Abarca-de Hoyos. 2004. Análisis de los factores de riesgo de la hipertensión arterial en Colima, México. Revista de Panamá Salud Pública 16: 402-407.

Fernández, S., M. López, A. Comas, E. García \& A. Cueto. 2003. Categorización de factores psicosociales asociados al cumplimiento farmacológico antihipertensivo. Psicothema 15: 82-87.

García, D., J. Álvarez, R. García, J. Valiente \& A. Hernández. 2009. La hipertensión arterial en la tercera edad. Revista Cubana de Medicina 48 (2). [Downloaded 2010 June 1]: http:// scielo.sld.cu/scielo.php?script=sci_arttext\&pid=S003475 $232009000200007 \&$ lng=es\&nrm=iso\&tlng=es.

Holguín, L., D. Correa, M. Aivillaga, M. Cáceres \& M. Varela. 2006. Adherencia al tratamiento de Hipertensión Arterial: Efectividad de un programa de intervención biopsicosocial. Universitas Psychologica 5: 535-547.

Johnell, K., L. Råstam, T. Lithman \& J. Merlo 2005. Low adherence with antihypertensives in actual practice: the association with social participation - a multilevel analysis. BioMed Central Public Health 5: 1-7.

Lara, A., R. Martín, G. Pastelín, C. Aguilar, F. Attie \& O. Velásquez. 2004. Hipercolesterolemia e hipertensión arterial en México, consolidación urbana actual con obesidad, diabetes y tabaquismo. Archivos de Cardiología 74: 233-245.

La Rosa, Y., L. Martín \& H. Bayarre. 2007. Adherencia terapéutica y factores psicosociales en pacientes hipertensos. Revista Cubana de Medicina General Integral 23: 1-5.

Márquez-Contreras, E. \& M. Figuera-Von Wichmann. 2009. Evaluación de la situación actual del cumplimiento terapéutico en la hipertensión arterial en España, en opinión de los pacientes. Proyecto Cumplex II. SEMERGEN 35: 367-373.

Martín, L., H. Bayarre, Y. La Rosa, M. Orbay, J. Rodríguez, F. Vento \& M. Acosta. 2007. Cumplimiento e incumplimiento del tratamiento antihipertensivo desde la perspectiva del paciente. Revista Cubana de Salud Pública 33: 1-10.

Martínez, J. \& I. Fernández. 2006. ¿Es la raza un criterio útil en la práctica médica? Revista Cubana Médica General Integral 22: $1-9$.

Méndez-Chacón, E. \& L. Rosero-Bixby. 2007. Prevalencia de hipertensión en adultos mayores de Costa Rica. Población y Salud en Mesoamérica 5 (1). [downloaded 2010 August 2]: http://dialnet.unirioja.es/servlet/ articulo?codigo $=2488418$.

Núñez, J., M. Martínez, M. Bes- Rastrollo, E. Toledo, J. Beunza \& A. Alonso. 2009. Consumo de alcohol e incidencia de hipertensión en una cohorte mediterránea: el estudio SUN. Revista Española de Cardiología 62: 633- 641.

Organización Mundial de Salud. 2004. Adherencia a los tratamientos a largo plazo, pruebas para la acción. OMS, Washington, D.C., USA. 
Organización Panamericana de la Salud. 2007. Iniciativa Centroamericana de Diabetes (CAMDI): encuesta de diabetes, hipertensión y factores de riesgo de enfermedades crónicas. Villa Nueva, Guatemala, 2006. OPS, Washington, D.C., USA.

Ortiz, M \& E. Ortiz. 2007. Psicología de la salud: Una clave para comprender el fenómeno de la adherencia terapéutica. Revista Médica de Chile 135: 647-652.

Palacín, F., C. Silva \& L. Krotter. 2002. Factores cognitivos en la adherencia al tratamiento. Congreso Internacional de Psiquiatría, Buenos Aires, Argentina.

Palomo, I., G. Torres, M. Alarcón, P. Maragaño, E. Leiva \& V. Mujica. 2006. Alta prevalencia de factores de riesgo cardiovascular clásicos en una población de estudiantes universitarios de la región centro sur de Chile. Revista Española de Cardiología 59: 1099-1105.

Pavón de Paz, I.C. Alameda \& O. Roldán. 2006. Obesidad y menopausia. Nutrición Hospitalaria 21: 633- 637.

Redon, J. \& E. Lurbe. 2007. Hipertensión arterial y obesidad. Medicina Clínica de Barcelona 129: 655-657.

Rivas, J., C. Gutiérrez \& J. Rivas. 2008. Tratamiento y costos farmacológicos de la Hipertensión Arterial no complicada en un hospital regional. Revista Peruana de Cardiología 34: 181-190.

Suárez, C. \& R. Gabriel. 2000. Epidemiología de la Hipertensión Arterial en España. Cardiovascular Risk Factors 9: 239-246.

Article edited by Vanessa Nielsen-Muñoz 


\section{APPENDIX 1}

Questionnaire for the Evaluation of Therapeutic Adherence in Hypertense Patients

\section{CUESTIONARIO DE EVALUACIÓN DE ADHERENCIA TERAPÉUTICA EN PACIENTES HIPERTENSOS (con presión alta)}

(basado y adaptado del test de Morinsky y del cuestionario MBG)

Estimado funcionario:

Un saludo cordial. Se le solicita su colaboración para el estudio que se está realizando con pacientes hipertensos de las oficinas centrales de la institución. Nuestro objetivo es elaborar un registro, lo más detallado posible, de las personas hipertensas y determinar las acciones por tomar con el fin de mejorar la atención a esta población de acuerdo a sus necesidades.

La herramienta para recoger la información se divide en dos partes: una de datos personales y otra, relacionada propiamente con el tratamiento de hipertensión arterial (presión alta).

Cabe anotar que la información que usted proporcione será tratada con absoluta confidencialidad y los resultados serán dados a conocer en forma grupal.

A continuación le solicitamos que complete el siguiente cuestionario. 

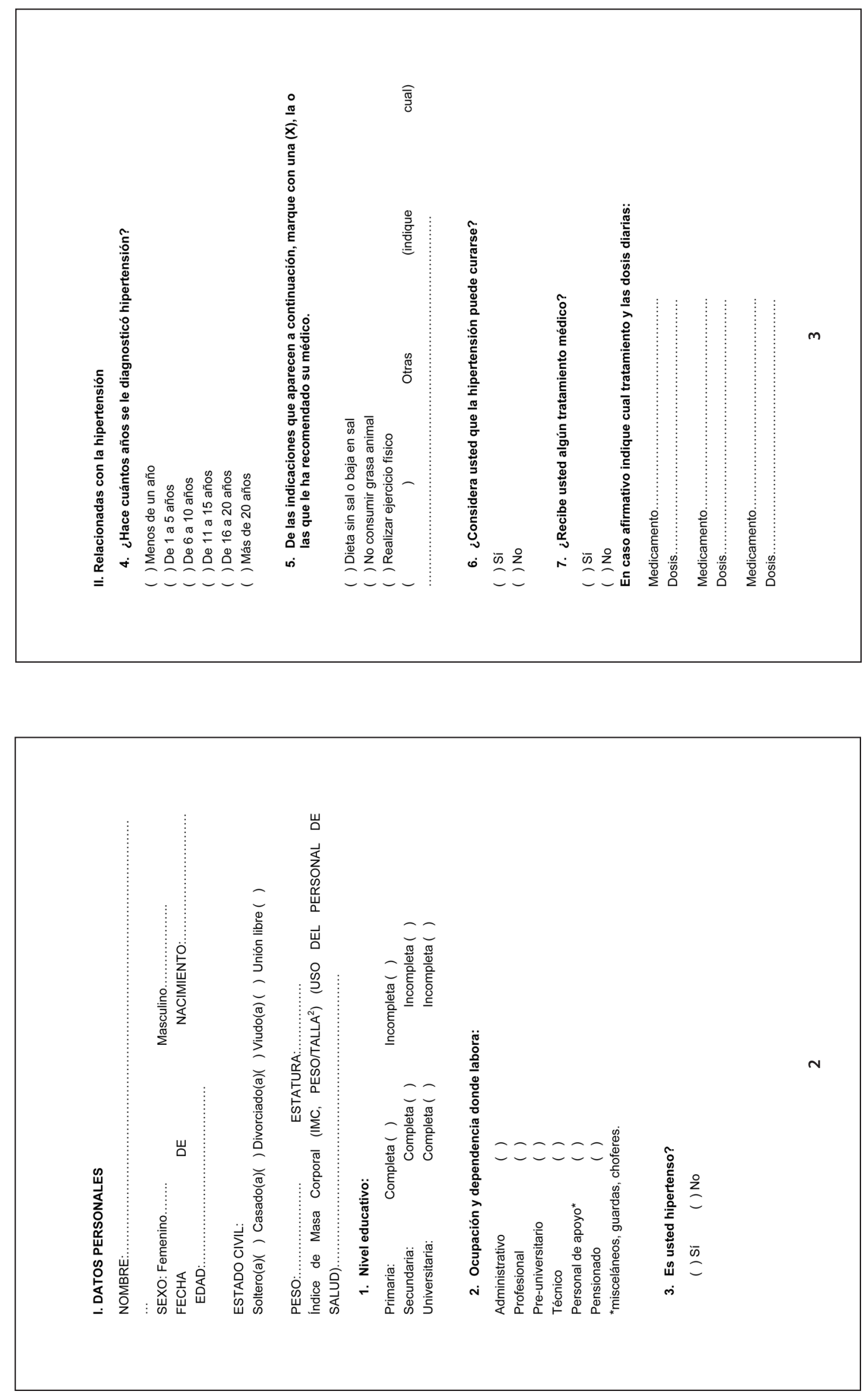

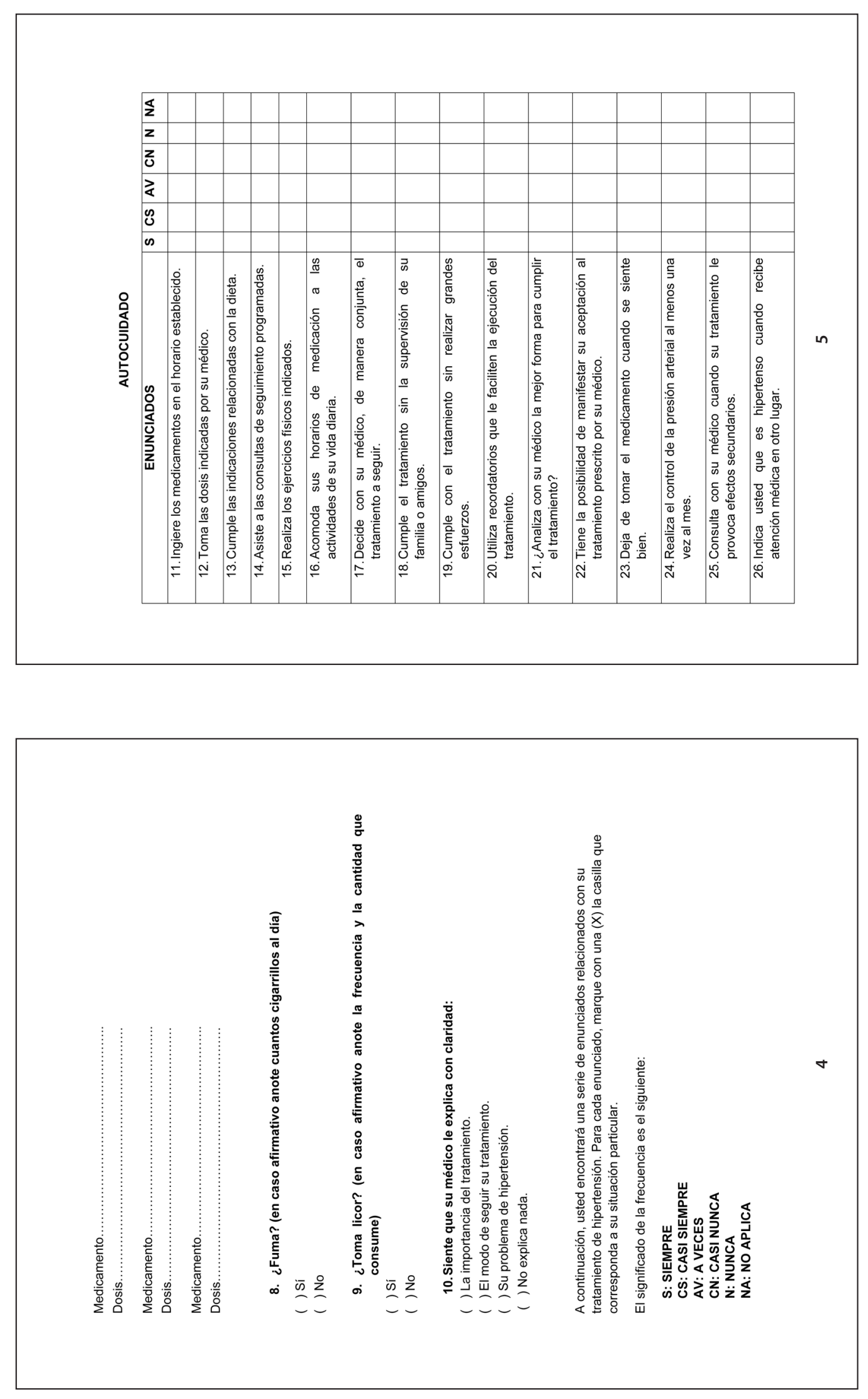

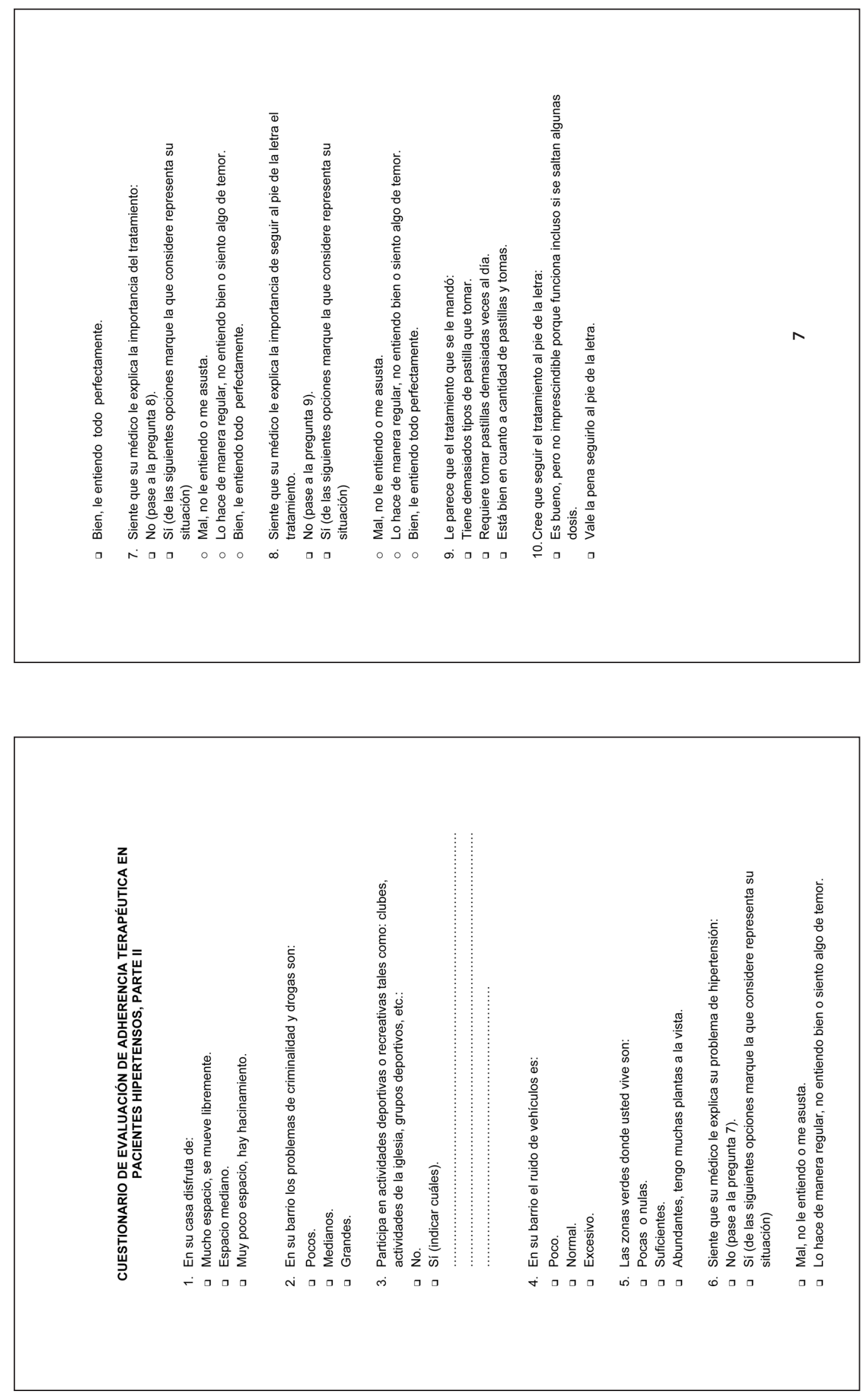